\title{
Living with Waste: Major Sources of Worries and Concerns about Landfills in Lagos Metropolis, Nigeria Olorunfemi, Felix B*.
}

\begin{abstract}
There is widespread public perception that landfills represent unacceptable risks to human health and environment. However, while there is an extensive literature on the impact of landfills in the developed countries, only few exist in African countries. Furthermore, few empirical studies have attempted to ascertain the individual and community level impacts around existing facilities. This is one part of a twin paper that addresses the individual and community level impacts around landfills in Lagos metropolis. While this paper examines the major sources of worries and concerns about landfills in Lagos metropolis, the second paper examines the coping mechanisms in response to impacts experienced among residents living in close proximity to the landfills. A structured questionnaire was the main instrument used in the collection of data for the study. The sample size consists of 930 heads of households in the two locations used for the study (488 in Olushosun and 442 in Abule-Egba). It focused on the nature of geographical variations and intensities of the impacts with distance from the sites. The outcome of the study shows that landfills within Lagos metropolis are uncontrolled and do not conform to international standards of landfill operations. The results reveal that the NIMBY syndrome clearly manifests in that respondents consistently placed high premium on negative externalities of landfills. Specifically, odour, smoke (from burning of wastes), noise, flies and rodents, aesthetics and water pollution were the most frequently mentioned environmental problems, while psychological disturbance, nausea, and diarrhoea were the most frequently mentioned health problems.
\end{abstract}

Keywords: Landfills; Environment; Risk; Perception; Lagos.

\section{Introduction}

Dublic consensus has long held that landfills are not a favourable usage of land (Carter, 1989; Adeola, 2000; Martynaiak et al, 2007). Consequently, locating environmentally noxious land uses such as landfills has become very problematic in many parts of the world today as opposition to such facilities seems to rise in both frequency and intensity (Zeiss and Lesfrud, 1996; Bourke, 1994; Wakefield and Elliott, 2000). Finding solutions to issues in waste disposal is becoming increasingly difficult. The process of siting a waste disposal facility, even for non-hazardous wastes, creates uncertainty, anxiety, and unrest in the surrounding communities. Local populations are becoming increasingly opposed to facilities which they perceive may threaten their environment and their health (Olokesusi, 1994; Coung, 2003).

Issues related to the disposal of waste pose important challenges for many communities not only in the developed countries, but also in developing countries due largely to the perception of risk to human health and the environment. There is a high degree of public awareness of these issues as the popular media frequently contain accounts of NIMBY (Not-In-My-Back-Yard), reactions to LULUs (Locally Undesirable Land
Uses)(Munton, 1996; Elliott et al, 1993; Ostry, 1993), particularly since the occurrence of high profile toxic contamination events like Love Canal (Levine and Stone, 1986) and Three Mile Island (Baum et al, 1982). In particular, public concern over the possible toxic effects of exposure to environmental contaminants continues to grow in the wake of these highly publicized events (Love Canal, Three Mile Island, Bhopal, Chernobil and St. Basile-leGrande). This is evidenced in the public opinion literature which indicates firstly, that worry and concern about environment and health have increased steadily over the past two decades and secondly, that the increase is associated with widely publicized environmental disasters (Baxter, 1992; Elliott, 1998).

While there is an extensive literature on the impact of hazardous waste facilities such as landfills in the developed countries, only a few exist in African countries (Olokesusi, 1994; Arimah and Adinnu, 1995). Much as these studies are useful for policy formulation and environmental management, very few empirical studies in Nigeria have attempted to ascertain the perception of host communities concerning landfills in general especially in large urban areas. But more importantly, though there exists a substantial

* Department of Physical Development, Nigerian Institute of Social and Economic Research (NISER), Ibadan, Nigeria. felixba2000@yahoo.com 
literature relating to NIMBY reactions to waste facilities siting proposals, much less is known about individual and community level impacts around existing facilities in Nigeria. Broadly, therefore, this research examines the major sources of worries and concerns about landfills in Lagos metropolis.

\section{Conceptual Framework and Literature Review}

The theoretical foundation for this study is environmental stress and coping theory (Lazarus and Folkman, 1984). It has been argued that the environmental stress and coping literature is closely connected to the risk perception literature vis-à-vis the mechanisms (i.e. perceptual processes) used to appraise threat (Taylor et al, 1993). Psychosocial impacts research focused on psychosocial impacts of exposure to environmental contaminants (Elliott and Taylor, 1996). The scope of such research is based on: (a) the awareness and prevalence of psychosocial impacts of exposure; (b) the relative absence of theory and empirical evidence to explain their determinants; and (c) uncertainty as to ways to intervene to effectively reduce their adverse effects on individual and community well being. While past researches has concentrated mainly on the physical health effects of exposure to environmental contaminants (e.g. cancer and adverse reproductive outcomes), increasing attention is now being turned to the psychosocial impacts of exposure defined as a complex of distress, dysfunction and disability manifested in a wide range of psychological, social and behavioural outcomes, as a consequence of actual or perceived environmental contamination (Baum et al, 1985; Elliott, 1998).

Baum et al (1985) define environmental stress as "a process by which environmental events threaten, harm or challenge an organism existence or well being and by which the organism responds to this threat". A useful psychosocial model of response to environmental stress is that provided by Lazarus and Folkman (1984). It contends that response to environmental stress is divided into two stages: primary appraisal, whereby the individual perceives an environmental stressor as a threat, harm, or a challenge; and secondary appraisal, whereby one of two coping strategies is selected: i) problem-focused coping (e.g. joining citizens action group); or

ii) emotion-focused coping (e.g. adjusting attitudes towards the stressor).

The occurrence of environmental stress the experience of psychological effects, and the choice of coping response are dependent upon four types of mediating factors, relating to the stressor (Evans and Jacobs, 1982, Sims and Baumann, 1983), the individual (Evans and Jacobs, 1982; Sims and Baumann, 1983), the social network (Edelstein, 1988), and the wider community system (Edelstein, 1988). Further, it involves an interactive process whereby the mediating factors not only influence psychological effects and responses but also each other. Psychological reactions to environmental contamination and in this case to waste disposal facilities have been found to occur within community systems (Elliott et al, 1993,). They are socially and culturally mediated in complex ways which are to some degree unique to the particular study setting.

\section{The Study Area}

The study area for this research is the Lagos metropolis. However, specific areas where the landfills areas are located are concentrated upon. There are presently three landfills in Lagos namely, the Olushosun, Abule Egba and Solous landfills. However, only Olushosun and Abule Egba landfills were chosen for this study. Apart from the fact that these two landfills are the most utilized, their contrasting geographical location in medium and high density residential areas respectively and their differences in sizes and operations all combined to justify the choice of the two landfills

The choice of the study area is justified on many grounds. For instance, the waste handling patterns and underlying attitudes of the urban population influences the functioning of municipal solid waste management systems, and these factors are, themselves, conditioned by the people's social and cultural context (Schubleller, 1996). The character of waste management tasks and the technical and organizational nature of appropriate solutions depend a great deal on the economic context of the country and/or city in question and, in fact, on the economic situation in the particular area of a city. Without any shade of doubt, solid waste is currently one of the biggest environmental 
problems commonly experienced in the Lagos metropolis, as in many other Nigerian urban centers. There has been a constant upswing in the annual volume of solid waste generated in various cities and towns in the country. Lagos is however in the lead in the amount of solid waste generated yearly in the country.

\section{Methodology}

Both secondary and primary data were utilized for this study. The secondary data included data on landfills from Lagos Waste Management Authority (LAWMA) and valuation data from Lagos State Valuation Office (LSVO). Data collected from LAWMA include information on the locational characteristics of the sites such as the geographic and topographic data while the data collected from LSVO were the number of properties within three kilometers away from the landfill sites.

A structured questionnaire was the main instrument used in the collection of the primary data. Socio economic characteristics are associated with people's perception of impact of facilities (McClelland et al, 1990). Therefore in this study, a number of socio economic variables of the respondents were examined. They are; age of household heads, marital status, income, number of persons in the household, education, occupation, length of stay in the area and in the house, type of building occupied by household, and the tenural status of the household (owner occupier or rented), among others. Educational achievement was particularly important as a surrogate for income, or socio economic status.

The sample size consists of 930 heads of households in the two locations (488 in Olushosun and 442 in Abule-Egba). The sample constitutes $3 \%$ of households out of the total 3, 4021 residential properties within three-kilometer radius of the two landfill sites. The distance was stratified into three concentric zones round the two sites; $\leq 1 \mathrm{~km}$, $1.1-2 \mathrm{~km}$ and $2.1-3 \mathrm{~km}$.

The statistical analysis of data involved basic descriptive univariate statistics (frequency counts, percentages, means, and standard deviation). In addition, inferential statistics (chi-square) was used to provide more explanations on the data.

\section{Discussion of Results \\ a) Socio-Economic Characteristics of Respondents}

Results of the analysis show that the mean age of the household heads was 44.94 and 45.20 in Olushosun and Abule-Egba landfill sites, respectively. More than 90 per cent of the respondents were over 30 years, while only 16.7 per cent(Olushosun) and 9.6 per cent (Abule-Egba) respondents were 30 years and below. This implies that almost all the respondents were adults who could speak authoritatively on behalf of their family members. Furthermore, the mean number of persons residing in each household was 5.62 and 6.40 in the two locations. This indicates that the households, in the study area, are fairly large due to the fact that most of the houses have 2 or 3 apartments. Its implication for this study is that more people are at a risk of suffering from the negative impact of landfills. This shows that more people will be at risk if there is an outbreak of disease resulting from the operation of the landfills in their neighborhood. The length of stay in an area is relevant, because the longer an individual is exposed to a landfill site, the higher the level of negative impact suffered. The mean length of stay, was 7.19 and 7.65 years for Olushosun and Abule-Egba landfill sites, respectively. This implies that many of the respondents have lived long enough within the landfill neighbourhoods to experience its negative impact. The mean values of socioeconomic survey of the study area are presented in Table 1

Furthermore, the results of the analysis revealed that men constituted the highest proportion of respondents in both locations (78.0 per cent and 83.1 per cent in Olushosun and Abule-Egba respectively), moreover, the majority of the households were headed by men. Only in few households $(22.0$ per cent and 17.0 per cent for Olushosun and Abule Egba respectively) were headed by women.

Those with higher education constituted more than half of the total number of respondents in the two locations, in Olushosun community, those who had secondary school and higher education constitute 83.3 per cent while AbuleEgba had 79 per cent. Showing that the level of education of household heads is slightly higher in Olushosun than Abule-Egba. The reason for this is that the level of literacy in Nigerian urban areas, especially in Lagos, is 
higher than that of rural areas, due to a concentration of higher institutions of learning and the in-migration of educated people from rural areas in search of employment opportunities. The high level of literacy is considered advantageous for the purpose of this study, considering the fact that knowledge plays a significant role in impact studies.

In Olushosun close to two-thirds of the respondents were tenants (68.9 per cent), while it is lower in Abule-Egba (56.8 per cent). The implication of the high percentage of tenants, in the two locations, is that community cohesion will be reduced, that is local attachment will be low and tenants can easily relocate unlike homeowners. Secondly, tenants are usually reluctant to pay for environmental quality (contingent valuation) in areas that host locally unwanted land uses (LULUs) unlike homeowners (Sims and Baumann, 1983).

b) Perceived Risks Environmental Risks

One of the major reasons for opposition to siting of landfills is the perceived environmental hazards or contaminations that are associated with them. This fear becomes heightened when these landfills are located, in essentially residential neighbourhoods. From the initial (pre-field) oral interview conducted among residents of both sites, the major environmental issues involved in the location and operation of the landfills were revealed by residents. This information coupled with the review of literature on major environmental issues in landfill operation, informed the design of the questionnaire.

The reliability co-efficient (alpha) for the items is very high (0.849 for Olushosun and 0.882 for Abule-Egba). The descriptive statistics for the major environmental concerns of respondents are presented in Table 2.

Table 2, revealed that, noise, aesthetics odour and water pollution are the most frequently mentioned environmental problems associated with the location of the landfills. For Abule-Egba site, noise, aesthetics, visibility are the major environmental problems mentioned. Not all the environmental problems showed a marked variation among the different zones. However, odour, visibility, flies and rodents, air pollution, dirt and insect and cockroaches showed a decrease in concern from zone 1 to zone 3 . This implies that concerns about these problems are higher among residents closer to the landfill site. Traffic obstruction is particularly found to be a serious problem in Abule Egba landfill site because the landfill is located by the major roadside. The illegal dumping of wastes, coupled with the activities of cart pushers have seriously led to traffic problem within the area. Oftentimes, motorists have to contest for the narrow lane left for vehicles. This often led to traffic hold up during most part of the day.

Oral interview of the residents closer to the landfill and personal observation during the fieldwork revealed that odour is a major problem with landfill operations. This is especially true in Abule-Egba where the dumping of wastes into the landfill is very much uncontrolled. This problem becomes more worrisome considering the fact that the landfill is located in a high-density residential area. This is the basis for the anxiety over the health problems that residents perceive the landfill could cause.

A one-way analysis of variance was used to test if there is any significant variation in the perception of environmental impacts among residents in different zones in the two locations. The result of the analysis shows that the $\mathrm{F}$ values obtained for Olushosun and Abule Egba were 1.437 and 3.383 respectively. The value for Olushosun was not significant $(\mathrm{P}=$ 0.239) while the value for Abule Egba was significant $(\mathrm{P}=.035)$. This implies that there is no significant variation in the perception of environmental impact of landfills among respondents in the different zones in Olushosun while the reverse is the case in Abule Egba.

\section{c) Perceived Risks Health Risks}

Health risk perception plays an ongoing role in the public response to environmental exposures (Elliott et al, 1993; Eyles, 1993). Essentially, relationships between an environmental contaminant and health are mediated by perceptions of the 'exposure' which are in turn influenced by a host of individual and contextual factors (Kasperson et al, 1988, Cutter, 1993). Public opinion literature indicates firstly, that worries and concern about environmental and health has increased steadily over the past two decades and secondly, that the increase is associated with widely publicized environmental disasters (Elliott, 1998).

From oral interviews conducted during the fieldwork, health-related issues were a major concern of the respondents. These 
concerns were more frequently mentioned among residents closer to the landfill sites. Respondents were asked to rate their present condition of health. This question was informed by the fact that the location of the landfill can affect the perception of the health status of the respondents. Responses from residents in the three zones around the two locations are presented in Table 3.

There are no marked differences in self-health rating among the respondents in the three zones around the two landfill sites. However, those who rated their health as being good have the highest percentages in all the zones. In Olushosun site, self-health rating tends to show a decrease away from the site. This is not the case in Abule-Egba. However, observations during the field interview revealed that generally, people do not want to reveal their true state of health to the interviewers. Some respondents even tied the issue of their health to religion.

Specifically, some major health indicators that could be impacted on by the operation of landfills were measured by seven questions that asked respondents to rate how much the location of the landfills has affected their health. The reliability co-efficient (alpha) for Olushosun and Abule-Egba is 0.84 and 0.86 respectively. The result of this analysis is presented in Table 4.

Perception of negative health impact is seen to be generally higher among the respondents around the Olushosun site than the Abule-Egba site. Another fact that emerged from the table is that perception of health impact is higher in zone 1 in Olushosun than the other zones. The reverse is however the case in Abule-Egba site where the perception is lower is zone 1 than any other zones. The reason could be the fact that respondents in zone 1 in Abule-Egba generally have a lower socio-economic status than other zones. The major health concerns as revealed by the analysis is headache and nauseous feelings which they link to smoke and oduor coming from the landfills. This had the highest frequency of mention among the respondents in both locations.

A one-way analysis of variance was used to test if there is any significant variation in the perception of health impacts among residents in different zones in the two locations. From the analysis, the $\mathrm{F}$ values obtained for Olushosun and Abule Egba were 2.870 and 5.229 respectively. The value for Olushosun was not significant $(\mathrm{P}=0.58)$ while for Abule-Egba it was significant $(P=0.006)$. Again, this that there is no significant variation in the perception of health impact of landfills among respondents in the different zones in Olushosun while the reverse is the case in Abule Egba.

\section{Conclusion}

The findings of this study revealed that landfills in Lagos are not well managed and do not conform to international standards. This contributed largely to the perceived negative environmental and health impacts of the landfills by the respondents. Results revealed that there are variations in the perceived impacts of the landfills among the respondents. The effects of landfills are not expected to be uniformly circular since a host of factors, such as weather conditions (primarily wind direction), truck traffic, and the quality of landfill management, combine to determine the ultimate direction and extent of any potential landfill effect. However, not surprisingly, this paper showed that there is a negative gradient of major impact categories from the landfill analysed. In other words, the farther from the landfills, the weaker the impact of the nuisance factors associated with the landfills

A major implication of the results from this study is that future siting of waste facilities could become very problematic since those whose communities are expected to host the facilities are becoming increasingly familiar with the negative externalities of such facilities. Given this scenario, solid waste managers may be forced to site landfills in distant rural locations from the urban centers. Consequently additional disposal cost will have to be borne by haulage firms which will in turn pass the cost to consumers.

Potential applications of the research findings are linked to the purpose of the research: to determine the impacts of exposure to environmental contaminants on individuals and communities and to develop strategies to reduce their adverse effects. The findings contribute to our understanding of individuals and community reaction to and experiences of landfill and can be used to inform the processes used to site much needed new facilities. 



\section{References}

Adeola F.O (2000) "Endangered Community, Enduring People: Toxic Contamination, Health and Adaptive Responses in a Local Context" Environment and Behaviour, Vol. 32 No. 2 pp 209-249.

Arimah, B.C and Adinnu, I.F (1995) "Market Segmentation and the Impact of Landfills on Residential Property Values: Empirical Evidence from an African City". Netherlands Journal of Housing and the Built Environment, Vol. 10 No. 2 pp 157-170

Baum A., Fleming R. and Singer J.E. (1985) "Understanding Environmental Stress: Strategies for Conceptual and Methodological Integration". In, Advances in Environmental Psychology, Vol. 5, (Edited by Baum A and Singer J.E.), Earlbaum Associated, New Jersey.

Baum, A., Singer, J. E. and Baum, C.S. (1982) "Stress and the Environment". In Evans, G.W. (Ed.) Environmental Stress, Cambridge, U.K: Cambridge University Press.

Beck, U., (1992) "From Industrial Society to Risk Society: Questions of Survival, Social Structure and Economic Enlightenment". Theory, Culture and Society 9, 97 - 123.

Bourke Lisa (1994) "Economic Attitudes and Responses to Siting Hazardous Waste Facilities in Rural Utah". Rural Sociology Vol 59 No 3 pp 485-496

Carter, C. (1989) "Review of Sanitary Landfill Impacts on Property Values". Real Estate Appraiser and Analyst. Vol. 35 No 3 pp 43 $-47$.

Cohen, S., Evans, G.W., Stokols, D., Krantz, D.S. (1986) "Behaviour Health and Environmental Stress". Plenum, New York.

Cuong, L.D. (2003) "Institutional Issues for Landfill Sitting in Viet Nam: Practical Recommendations for Improvement”. A Thesis Submitted in Conformity with the requirements for the degree of Master of Engineering Graduate Department of Civil Engineering, University of Toronto, Canada. Elliot S.J. (1992). "Psychosocial Impacts in Populations Exposed to Solid Waste Facilities". Unpublished Ph.D. Thesis McMaster University, Department of Geography.
Elliott S.J. and Taylor. S.M. (1996) "Worrying About Waste: Diagnosis and Prescription". In: Munton, D. (ed.) Siting by Choice: Waste Facilities, NIMBY and Volunteer Communities. Washington. DC. Georgetown University Press. Pp 290-318

Elliott, S.J. (1998). "A Comparative Analysis of Public Concern over Solid Waste Incinerators". Waste Management and Research, Vol 16 No4 pp. $351-364$.

Evans G.W and Cohen S. (1987) "Environmental Stress". In: Handbook of Environmental Psychology. Vol. 2 Edited by Stokold D and Altman I. pp. 571 - 610 Wiley and Sons, New York.

Kasperson, R.E. O. Renn, P. Slovic, H. S. Brown, J. Emel, R. Goble, J.X. Kasperson, and S. Ratick, (1988) "The Social Amplification of Risk: A Conceptual Framework", Risk Analysis 18 No1, 177 - 187.

Lazarus R. and Folkman S. (1984) "Stress Appraisal and Coping". Springer, New York.

Lazarus, R. (1993). "Coping Theory and Research: Past, Present and Future". Psychosomatic Medicine. Vol 55 pp $234-247$. Martynaiak N.D; Hallman, W.K and Wandersman, A.H (2007) "The Case of the Pinewood Landfill: The Politics of Risk, Nationality, and the Disposal of Hazardous Wastes". Research in Social Problems and Public Policy. Vol. 14, pp. 73-91

Munton, D., (1996). "Hazardous Waste Siting and Democratic Choice". Georgetown University Press, Washington, DC.

Olokesusi, F. (1994) "Impact of the Ring Road Solid Waste Disposal Facility in Ibadan, Nigeria". NISER Monograph Series No 3. NISER, Ibadan

Ostry, A. Munton, D. and Castle, G. (1993) "Community Risk Perception and Waste Management: A Comparison of Three Communities". In: Munton, D. and Castle, G. (Eds) Proceedings, Symposium on the Siting of Hazardous Waste Treatment Facilities, Vancouver: University of British Columbia.

Sims J.H and Habumann D.D. (1983) "Educational Programs and Human Response to Natural Hazards". Environment and Behaviour 2., pp. 165 - 189. 
Taylor, S.M., S.J. Elliott, J. Eyles; J. Frank, M. Haight, D. Streiner, S. Walter, D. Willms, and N. White, (1993) "Psychosocial Impacts in Populations Exposed to Solid Waste Facilities". Final Report to the Ontario Ministry of Environment (McMaster University, Hamilton, Ontario, Canada,).

Wakefield, S. and Elliott, S. J. (2000) "Environmental Risk Perception and Well Being: Effects of the Landfill Siting Process in Two Southern Ontario Communities".
Social Science and Medicine. 50. pp. 1139 1154.

Washburn S.T., Brainard, J and Harris, R.H (1989) "Human Health Risks of Municipal Solid Waste Incineration". Environmental Impact Assessment Review. 9, 181-198

Zeiss, C, and Lesfrud, L. (1996) "Making or Breaking Waste Facility Siting Successes with a Siting Framework". Environmental Management. Vol. 20, No. 1, pp. 53-64.

Acknowledgement: I wish to thank Prof. A.S Gbadegesin of the Department of Geography, University of Ibadan, Ibadan, Nigeria for supervising the thesis which provided the foundation for this paper. Dr. Susan Elliott of McMaster University, Canada for the provision of materials for literature. I also thank the Council for the Development of Social Science Research in Africa (CODESRIA), Dakar, Senegal for financial support.

.Table 1: Mean Values of Socio-Economic Survey of the Study Area

\begin{tabular}{l|crrr}
\hline Mean values of Socio-Economic & Olushosun & \multicolumn{2}{c}{ Abule Egba } \\
\cline { 2 - 5 } characteristics & Mean & SD & Mean & SD \\
Age of Respondent & 44.94 & 13.69 & 45.20 & 12.91 \\
Length of stay in the Area & 7.19 & 5.77 & 7.65 & 6.24 \\
Length of stay in the House & 7.18 & 6.19 & 6.98 & 6.19 \\
No of persons in the Household & 5.62 & 3.11 & 6.40 & 3.24 \\
\hline
\end{tabular}

Source: Author's Analysis

Table 2: Descriptive Statistics for Major Environmental Concerns about Landfills

\begin{tabular}{|c|c|c|c|c|c|c|c|}
\hline \multirow{2}{*}{\multicolumn{2}{|c|}{ Environmental concerns }} & \multicolumn{3}{|c|}{ Olushosun } & \multicolumn{3}{|c|}{ Abule-Egba } \\
\hline & & Zone 1 & Zone 2 & Zone 3 & Zone 1 & Zone 2 & Zone 3 \\
\hline \multirow[t]{2}{*}{ Odour } & Mean & 3.83 & 3.89 & 3.26 & 2.96 & 2.86 & 2.15 \\
\hline & Std. Dev & 1.46 & 1.48 & 1.49 & 1.58 & 1.43 & 1.55 \\
\hline \multirow[t]{2}{*}{ Noise } & Mean & 3.43 & 3.33 & 3.42 & 3.64 & 3.74 & 3.78 \\
\hline & Std. Dev & 1.38 & 1.55 & 1.41 & 1.42 & 1.37 & 1.30 \\
\hline \multirow[t]{2}{*}{ Visibility } & Mean & 2.93 & 2.85 & 2.73 & 2.97 & 3.29 & 3.07 \\
\hline & Std. Dev & 1.46 & 1.45 & 1.37 & 1.55 & 1.34 & 1.52 \\
\hline \multirow[t]{2}{*}{ Aesthetics } & Mean & 3.30 & 3.52 & 3.29 & 3.72 & 3.75 & 3.56 \\
\hline & Std. Dev & 1.36 & 1.47 & 1.46 & 3.31 & 1.27 & 1.26 \\
\hline Traffic obstruction & Mean & 2.38 & 2.58 & 2.83 & 3.47 & 3.41 & 1.54 \\
\hline \multirow[t]{2}{*}{ Flies \& rodents } & Std. Dev & 1.38 & 1.46 & 1.22 & 2.31 & 1.38 & 1.51 \\
\hline & Mean & 2.78 & 2.58 & 3.19 & 1.42 & 2.91 & 2.72 \\
\hline \multirow[t]{2}{*}{ Air pollution } & Std. Dev & 1.40 & 1.34 & 1.29 & 2.31 & 1.43 & 1.46 \\
\hline & Mean & 2.79 & 2.57 & 2.36 & 1.40 & 2.74 & 2.44 \\
\hline \multirow[t]{2}{*}{ Water pollution } & Std. Dev & 1.35 & 1.40 & 1.32 & 2.96 & 1.46 & 1.44 \\
\hline & Mean & 3.35 & 3.21 & 3.45 & 1.42 & 3.26 & 3.18 \\
\hline \multirow[t]{2}{*}{ Dirt } & Std. Dev & 1.31 & 1.35 & 1.43 & 2.63 & 1.36 & 1.39 \\
\hline & Mean & 2.96 & 2.85 & 3.26 & 1.52 & 2.78 & 2.66 \\
\hline \multirow{3}{*}{$\begin{array}{l}\text { Insect } \\
\text { cockroaches }\end{array}$} & Std. Dev & 1.44 & 1.40 & 1.32 & 1.52 & 1.50 & 1.46 \\
\hline & Mean & 2.74 & 2.52 & 3.13 & 2.80 & 2.54 & 2.18 \\
\hline & Std. Dev & 1.30 & 1.34 & 1.25 & 1.33 & 1.34 & 1.29 \\
\hline \multirow[t]{2}{*}{ Others } & Mean & 2.85 & 2.75 & 2.87 & 2.62 & 2.70 & 2.63 \\
\hline & Std. Dev & 1.25 & 1.23 & 1.10 & 1.17 & 1.14 & 1.12 \\
\hline
\end{tabular}

Source: Author's Analysis 
Table 3: Respondents' Self Health Rating

\begin{tabular}{lrrrrrrrrrrrr}
\hline Rating & \multicolumn{4}{c}{ OLUSHOSUN } & \multicolumn{4}{c}{ ABULE-EGBA } \\
& \multicolumn{1}{c}{ Zone 1 } & \multicolumn{1}{c}{ Zone 2 } & \multicolumn{2}{c}{ Zone 3 } & \multicolumn{3}{c}{ Zone 1 } & \multicolumn{3}{c}{ Zone 2 } & Zone 3 \\
& $N o$ & $\%$ & No & $\%$ & No & $\%$ & No & $\%$ & No & $\%$ & No & $\%$ \\
Excellent & 28 & 17.7 & 24 & 14.1 & 30 & 18.8 & 39 & 21.7 & 18 & 14.0 & 30 & 22.6 \\
Good & 108 & 68.4 & 106 & 62.4 & 85 & 53.1 & 105 & 58.9 & 88 & 68.0 & 73 & 54.9 \\
Fair & 21 & 13.3 & 29 & 17.1 & 42 & 26.1 & 34 & 18.9 & 19 & 14.7 & 24 & 18.0 \\
Poor & 1 & 0.6 & 11 & 6.5 & 3 & 1.9 & 2 & 1.1 & 4 & 3.1 & 6 & 4.5 \\
Total & 158 & 32.4 & 170 & 34.8 & 160 & 32.8 & 180 & 40.7 & 129 & 29.2 & 133 & 30.1 \\
\hline
\end{tabular}

Source: Author's Analysis

Table 4: Descriptive Statistics for Major Health Concerns about Landfills

\begin{tabular}{|c|c|c|c|c|c|c|c|c|c|c|c|c|}
\hline \multirow[t]{3}{*}{ Health Concerns } & \multicolumn{6}{|c|}{ OLUSHOSUN } & \multicolumn{6}{|c|}{ ABULE-EGBA } \\
\hline & \multicolumn{2}{|c|}{ Zone 1} & \multicolumn{2}{|c|}{ Zone 2} & \multicolumn{2}{|c|}{ Zone 3} & \multicolumn{2}{|c|}{ Zone 1} & \multicolumn{3}{|c|}{ Zone 2} & \multirow{2}{*}{$\begin{array}{r}\text { Zone } 3 \\
\text { S.D }\end{array}$} \\
\hline & Mean & S.D & Mean & S.D & Mean & S.D & Mean & S.D & Mean & S.D & Mean & \\
\hline Psychological disturbance & 3.01 & 1.35 & 2.94 & 1.56 & 2.52 & 1.53 & 2.57 & 1.41 & 2.82 & 1.50 & 2.52 & 1.49 \\
\hline Skin Irritation & 3.21 & 1.44 & 3.09 & 1.47 & 3.57 & 1.36 & 2.51 & 1.32 & 3.09 & 1.50 & 2.60 & 1.42 \\
\hline Water Related disease & 3.49 & 1.34 & 3.07 & 1.36 & 3.76 & 1.47 & 2.64 & 1.38 & 2.98 & 1.45 & 3.02 & 1.41 \\
\hline Accidents/Injury & 2.75 & 1.30 & 2.59 & 1.44 & 2.08 & 1.22 & 3.24 & 1.33 & 3.88 & 1.27 & 3.63 & 1.20 \\
\hline Dysentery/Diarrhoea & 3.59 & 1.26 & 3.24 & 1.28 & 3.28 & 1.47 & 3.00 & 1.29 & 3.38 & 1.30 & 3.31 & 1.32 \\
\hline Headaches/Nausea & 3.80 & 1.31 & 4.01 & 1.30 & 3.91 & 1.10 & 3.62 & 1.31 & 3.74 & 1.34 & 3.71 & 1.29 \\
\hline Children diseases & 3.43 & 1.46 & 2.90 & 1.51 & 3.11 & 1.62 & 2.69 & 1.38 & 3.04 & 1.62 & 2.68 & 1.52 \\
\hline
\end{tabular}

Source: Author's Analysis 